\title{
Pendidikan Karakter dalam Keluarga Single Parent di Desa Talang Belido
}

\author{
Muhammad Rafii ${ }^{* 1}$, Mastikawati ${ }^{2}$, Dewi Tumatul Ainin ${ }^{3}$, Nori Nopita \\ $\mathrm{Sari}^{4}{ }^{4}$ Nazoma $^{5}$, Zulkifli $^{6}$, Melati $^{7}$ \\ Institut Agama Islam Muhammad Azim, Jambi, ${ }^{1,2,3,4,5,6}$ UIN STS Jambi, ${ }^{7}$ \\ Email: Muhammadrafii@iaima.ac.id, ${ }^{1}$ mastikaika333@gmail.com, ${ }^{2}$ \\ dewi.t.ainin@gmail.com, ${ }^{3}$ Novitaahmadelquraisy@gmail.com, ${ }^{4}$ Nazomajbi@gmail.com, ${ }^{5}$ \\ zulk9028@gmail.com, ${ }^{6}$ melati2471@gmail.com.7
}

\begin{abstract}
Character education is so important with the consideration that the digital generation is increasingly displaying behavior in the real world and the virtual world unnaturally. It is worth exploring how a family educates children in their life or family environment. However, what is of concern in this article is character education in single parent families in Talang Belido Village. By utilizing primary and secondary data, obtained from observations and interviews as well as documentation, the researcher attempted to collect relevant data related to the topic of this research. Data were analyzed following data reduction techniques, data display, and data verification to draw conclusions. This article draws the conclusion that character education in single parent families gets great attention for the head of the family. Even though they realize they have no knowledge, experience and are able to give advice to their children. Character values that are often conveyed are honesty, religious and respect for others. However, it is also known that the obstacles experienced by single parent families are the influence of the children's playing or socializing environment, the educational background of the parents, and the availability of insufficient time to fully interact with their children.
\end{abstract}

Keywords: Character Education, Family, Single Parent

\begin{abstract}
Abstrak
Pendidikan karakter demikian penting dengan pertimbangan generasi digital semakin menampilkan perilaku di dunia nyata maupun dunia maya secara tidak wajar. Hal tersebut patut ditelusuri bagaimana sebuah keluarga mendidik anak dalam kehidupan atau lingkungan keluarganya. Namun, yang menjadi perhatian dalam artikel ini ialah pendidikan karakter dalam keluarga single parent di Desa Talang Belido. Dengan memanfaat data primer dan sekunder, yang diperoleh dari observasi dan wawancara serta dokumentasi, peneliti berupaya mengumpulkan data-data relevan terkait topik penelitian ini. Data
\end{abstract}




\begin{abstract}
dianalisis mengikuti teknik reduksi data, display data, dan verifikasi data hingga penarikan kesimpulan. Artikel ini menarik kesimpulan bahwa pendidikan karakter dalam keluarga single parent mendapat perhatian besar bagi kepala keluarga. Meskipun mereka menyadari tidak memiliki pengetahuan, pengalaman dan mampu memberi nasehat kepada anaknya. Nilai karakter yang kerap disampaikan ialah kejujuran, religius dan menghargai orang lain. Namun, diketahui pula bahwa hambatan yang dialami keluarga single parent ialah pengaruh lingkungan bermain atau bergaul anak, latar belakang pendidikan orang tua, dan ketersediaan waktu yang tidak memadai untuk berinteraksi secara penuh kepada anak-anaknya.
\end{abstract}

Kata Kunci: Pendidkan Karakter, Keluarga, Single Parent

\title{
PENDAHULUAN
}

Pendidikan karakter belakangan memicu sorotan tajam dari sejumlah pihak dan pemangku kebijakan. Beranjak dari persoalan di lembaga pendidikan yang bertugas menanam, membentuk dan menggiatkan nilai karakter tertanam dan termuat dalam setiap kepribadian seorang siswa dan anak. Alasan tersebut mendorong Kementerian Pendidikan Nasional menekankan aspek karakter diterapkan pada setiap institusi pendidikan yang menuntut pendidikan karakter terhadap anak maupun peserta didik perlu mendapat perhatian besar (Sholihah dan Windy Zakiya Maulida, 2020, p. 49).

Menurut al-Ghazali pendidikan karakter adalah inti ajaran agama Islam, sebagaimana Nabi Muhammad mendapat tugas memperbaiki karakter manusia (Saepuddin, 2019, p. 87). Karakter adalah sekumpulan nilai yang termuat dalam setiap individu melalui berbagai proses; pendidikan, percobaan, pengalaman, pengaruh lingkungan dan pengorbanan. Oleh karena itu, karakter tidak dapat dimiliki tanpa ada usaha atau proses yang dilaluinya, misalnya pembentukan, penumbuhan, dan pembangunan (Muchlis. M. Hanafi, 2010, p. 78).

Proses pendidikan formal menjadikan guru sebagai figur dan role model untuk menerapkan pendidikan karakter pada pendidikan formal (Ni Putu Suwardani, 2020, p. 56). Demikian pula orang tua harus terlibat dalam penanaman pendidikan karakter sebagai usaha aktif sejak dalam keluarga. Karena pendidikan tersebut dapat efektif, jika semua elemen ikut serta mendidik dalam kehidupan sosialnya (Mustoip et al., 2018, p. 186). Dengan demikian memperkuat pendidikan karakter dalam kehidupan semakin penting, sebagaimana terbukti dengan terbitnya Peraturan Presiden Nomor 87 Tahun 
2017 yang memuat ajakan untuk berkolaborasi setiap elemen dalam mewujudkan pendidikan karakter (Otib Satibi Hidayat, 2020).

Keluarga sebagai lingkungan pendidikan pertama sangat penting dalam membentuk karakter anak, karena dalam keluarga, anak-anak pertama kali berkenalan dengan nilai-nilai dan norma (Setiawati, 2018, p. 94). Keluarga adalah unsur utama dalam membentuk kepribadian anak. Karena ia merupakan satu sistem sosial yang berperan penting dalam membangun landasan atau dasar pendidikan bagi anggota keluarga, terkhusus anak. Sebagaimana sekolah, keluarga sangat berarti bagi sistem pendidikan dalam menanam dan mendidik perkembangan karakter. Posisi strategis yang didudukinya merupakan alasan mendasar penanaman karakter dalam keluarga berpotensi untuk dilakukan (Marzuki, 2015). Peran keluarga dalam memberi pendidikan adalah faktor terpenting dalam membentuk perilaku dan sikap anak dalam berbagai hal; kepribadian, sosial dan emosional (Ulfiah, 2016, p. 76).

Keutuhan keluarga secara nyata memberi hasil berbeda dalam mendidik karakter anak. Dalam keluarga utuh, kasih sayang dapat terpenuhi, kemandirian dan permasalahan yang dialami anak lebih sedikit, dan taat pada orang tua. Sebaliknya keluarga single parent, kasih sayang pada anak tidak terpenuhi, anak bermasalah, tidak penurut, namun banyak ditemukan dalam keluarga tidak utuh anak yang mandiri (Sukiyani dan Zamroni, 2014). Bahkan anak dari keluarga single parent berdampak negatif terhadap semangat mereka untuk menempuh pendidikan, hal demikian merugikan anak-anak dari keluarga yang tidak utuh tersebut (Langea, Dronkersb, dan Wolbers, 2014, p. 329).

Single parent mengalami perjalanan hidup yang dinamis dan penuh dinamika. Single parent memiliki beban yang berat dan harus bertahan hidup untuk diri mereka sendiri dan anak-anak. Kesejahteraan single parent tidak harus meningkat meskipun pendapatan tinggi. Meskipun seorang ibu tunggal memiliki kehidupan yang relatif stabil, beban tetap sangat besar (Priyono Tri Febrianto, 2021, p. 28). Di tengah kehidupannya yang tidak mudah, seperti menghadapi tekanan ekonomi dan peran ganda, seorang single parent memperoleh tuntutan sebagai pendidik dan penanggung jawab atas semua persoalan keluarganya (Succy Primayuni, 2019). Hal tersebut menunjukkan bahwa anak dari keluarga single parent kurang baik dalam berbagai ukuran kesejahteraan dibandingkan anak yang tinggal dengan kedua orang tuanya.

Sejumlah penelitian menegaskan bahwa single parent sulit untuk memberi pengawasan terhadap perilaku anggota keluarganya. Salah satu penyebab utamanya ialah kesibukan single parent dalam mencari nafkah dan memenuhi 
kebutuhan ekonomi, namun sedikit waktu untuk memberi pendidikan karakter bagi anak-anaknya (Maslina Daulay 2017). Penelitian lain menilai keluarga single parent dalam hal sosial dan moralitas semakin tidak stabil di tengah kehidupan masyarakat. Tantangan utama bagi keluarga tidak utuh ini ialah karakter atau moralitas anggota keluarga yang memprihatinkan (Aghawenu, 2019). Meskipun demikian seorang single parent memiliki peluang dan kemampuan untuk memainkan peran motivator dan fasilitator bagi kelangsungan hidup anak (Rizka Khuswanal Mala, 2017). Karena pengembangan keterampilan sosial dan integrasi pendidikan karakter merupakan bagian penting dari keberhasilan pendidikan bagi seorang anak (Aynur Pala, 2011).

Desa Talang Belido merupakan salah satu desa yang terletak di pedesaan Muaro Jambi, Provinsi Jambi. Dari dokumentasi penulis ditemukan bahwa single parent di desa ini tergolong banyak dengan jumlah 10-15 single parent. Selain itu, wilayah pedesaan seperti Desa Talang Belido tidak menutup kemungkinan arus digital, teknologi dan informasi tertutup serapat mungkin. Terlihat generasi muda di wilayah ini, sangat familiar dan populer dengan beragam teknologi informasi yang tersedia dalam handphone maupun aplikasi lainnya. Alasan tersebut menguatkan bahwa pendidikan karakter rentan dari keberhasilan, jika melihat kasus anak-anak di lingkungan desa Talang Belido tergambar sedemikian.

Oleh karena itu, menelaah dan menjelaskan upaya pendidikan dan faktor penghambat dalam keluarga single parent dalam mendidik karakter anak merupakan sesuatu yang cukup memikat untuk diteliti. Dengan demikian penelitian ini menyoroti pada dua hal utama yaitu; pendidikan karakter yang dilakukan dalam keluarga single parent dan berbagai hambatan keluarga single parent dalam mendidik karakter kepada anggota keluarga, terkhusus anaknya.

\section{METODE PENELITIAN}

Penelitian ini dilakukan menggunakan metode kualitatif, peneliti berupaya mendeskripsikan dan menjelaskan nilai pendidikan karakter yang diberikan oleh ibu single parent dan faktor yang menghambat dalam pelaksanaan pendidikan tersebut. Pengumpulan data dilakukan dengan mengamati dan wawancara mendalam terhadap sembilan (9) partisipan single parent untuk memperoleh informasi dan data yang valid. Berdasarkan data tersebut peneliti menganalisis dengan mengikuti tahapan berikut: reduksi data, penyajian data, dan verifikasi serta penarikan kesimpulan. Dalam menguji akurasi data, peneliti melakukan wawancara pada waktu dan konteks berbeda untuk mendapatkan 
pernyataan dan informasi baru ataupun yang telah diulang pada wawancara sebelumnya. Peneliti menerapkan kerangka analisis tersebut dalam menganalisis berbagai informasi atau data diperoleh dari seluruh partisipan.

\section{HASIL DAN PEMBAHASAN}

\section{Pendidikan Karakter dalam Keluarga Single Parent Desa Talang Belido}

Single parent dalam mendidik anak, mereka menggunakan beberapa metode seperti: pemberian nasihat, merupakan penjelasan tentang kebenaran dan kemaslahatan dengan tujuan agar anaknya terhindar dari perbuatan tercela yang merugikan dirinya maupun orang lain. Mendidik karakter anak dalam keluarga single parent di Desa Talang Belido terus diajarkan meskipun terbatas, tetapi orang tua berusaha agar anaknya tetap mendapatkan pendidikan.

Salah satu sarana pendidikan karakter yang ditanamkan ialah melalui pendidikan agama, ia masih dipercaya dapat mendidik karakter anak di Desa ini, dikarenakan agama merupakan sumber ajaran dalam berperilaku dalam kehidupan sosial, baik bagi anak-anak maupun masyarakat luas. Dengan demikian single parent menjadikan pendidikan agama sebagai benteng moral dan akhlak anak-anak mereka.

Berdasarkan wawancara dengan salah seorang single parent dalam mendidik karakter anaknya ditemukan bahwa sebagai orang tua selalu berusaha memberikan nasehat pada anak, dan pengarahan tentang ajaran agama Islam terutama pada saat mereka sedang di rumah. Demikian juga ia menanamkan nilai-nilai agama Islam pada anaknya agar kelak mereka dapat tumbuh menjadi orang berguna bagi masyarakat. Di samping itu memberikan perhatian penuh agar tidak terpengaruh dengan lingkungan yang tidak benar (Rahana, 1 Juli 2021, Upaya Pendidikan Karakter).

Ungkapan di atas memperjelas bahwa pendidikan karakter anak menurut single parent tetap dimulai dari rumah, dengan nasehat dan arahan sesuai ajaran Islam. Hal demikian dilakukan dengan harapan agar anaknya mampu memberi manfaat bagi masyarakat sekitar. Dalam mengontrol kegiatan anak di luar rumah terus diperhatikan lingkungannya, teman sepermainan, dan pergaulannya.

Demikian juga dengan ibu Iyem memberikan pendidikan karakter kepada anaknya sedini mungkin tentang agama maupun aktivitas keagamaan lainnya. Lebih lanjut ia menjelaskan, sejak kecil anak-anak dilatih, diajar dan dididik tentang agama karena takut saat ia besar nanti akan jadi anak nakal, melawan orang tua, dan berandalan, karena tidak mengenal ilmu agama. Oleh 
karena itu ibu tersebut mengajar bacaan al-Quran, shalat dan lainnya serta melarang anaknya untuk tidak menghina kawannya, berkelahi dan berbohong (Iyem, 3 Juli 2021, Upaya Pendidikan Karakter).

Mendidik karakter memang bukan hal yang mudah, maka single parent secara terus menerus mengupayakan untuk membiasakan anak-anak agar tetap mengikuti arahan dan anjuran orang tua yang sesuai dengan ketentuan agama. Contoh di atas seperti diajari mengaji dan shalat, merupakan aktivitas yang dilakukan dalam rangka mengajarkan ketaatan kepada ajaran Islam.

Dengan demikian, baik masalah ibadah maupun soal perilaku dan karakter harus diberikan dan dibiasakan kepada anak yang disertai dengan kegiatan sehari-hari secara dini. Harapan untuk mendidik karakter bagi anak secara perlahan dapat diterima olehnya dan diikuti sesuai didikan orang tuanya.

Ibu Mardiana mengatakan bahwa pendidikan karakter pada anak-anak merupakan hal yang mendasar harus diberikan kepada anak. Karena di masa pertumbuhan dan perkembangan anak, mereka akan menyerap dan mengikuti secara sukarela ajaran, arahan ataupun perintah dari orang tua (Mardiana, 5 Juli 2021, tentang Pengetahuan Pendidikan Karakter).

Di Desa Talang Belido dapat dilihat bagaimana pengarahan orang tua dalam mendidik karakter anaknya agar tidak terpengaruh oleh hal-hal yang tidak dibenarkan baik oleh norma sosial maupun agama, hal demikian terlihat dari harapan ibu single parent dalam mendidik karakter anak ke arah yang lebih baik, karena agama mewajibkan setiap muslim untuk mendidik anak-anaknya agar mempelajari agama sedini mungkin. Di dalam keluarga, sebagai orang tua tunggal selalu mengajarkan anak untuk berprilaku baik, jujur, saling menolong, serta tidak menghina temannya. Sebagaimana semestinya dilakukan dalam agama, agar nanti memiliki kepribadian muslim yang bertakwa (Sumiati, 7 Juli 2021, Upaya Pendidikan Karakter).

Penegasan di atas menjelaskan bahwa sebagai umat Islam harus mendidik anaknya. Berbuat baik dalam berinteraksi dengan orang lain, baik dengan teman maupun orang tua, agar terus diperhatikan dalam pergaulan sehari-hari. Ibu Sumiati, mendidik dari hal yang selalu ditemui oleh anak, yaitu berbuat baik, tidak boleh mengejek teman mainnya. Hal demikian memperlihatkan bahwa orang tua tunggal seperti ibu Sumiati tersebut memiliki harapan yang besar yaitu menjadi anak yang memiliki kepribadian dan bertakwa.

Upaya pendidikan oleh single parent di Desa Talang Belido ini memberikan pendidikan karakter kepada anak-anaknya dengan langkah yang 
berbeda. Salah seorang single parent, dengan menekankan pada pembiasaan untuk berbuat baik. Sementara partisipan lain menitikberatkan pada ajaran agama Islam yang sangat dekat dan dipercaya dapat mendidik karakter anak sejak dini.

Desa Talang Belido, ditemukan bahwa orang tua tunggal memberi pendidikan melalui nasehat-nasehat, arahan, dan bimbingan kepada anaknya. Nasehat yang diberikan memuat perilaku sehari-hari, ajaran Islam, dan memberi pengawasan terhadap pergaulan anaknya. Hal ini menunjukkan bahwa orang tua tunggal sedang berupaya memberi pendidikan kepada anaknya.

Karena bagaimanapun anak sesungguhnya dapat memahami apa yang telah disampaikan oleh orang tuanya. Bahkan dengan arahan dan nasehat tersebut, mereka akan semakin kokoh terhadap pemahaman mereka yang mampu membedakan perubahan baik dan buruk, serta akibatnya (Thalib, 2010, p. 54). Namun, perlu disadari bahwa sesungguhnya hal tersebut pula yang akan membawa pada perkembangan moral anak ataupun remaja baik secara kognitif maupun kepribadian.

Melalui nasehat, dan pemberitahuan yang dilakukan orang tua tunggal, sesungguhnya telah melakukan internalisasi kepada anaknya agar menjunjung tinggi akhlak dan perilaku yang mulia di tengah masyarakat. Meskipun demikian bukan berarti anak dapat mengikuti secara total kepada orang tuanya, sebagaimana diperlihatkan dalam temuan penelitian ini. Hal tersebut memperkuat bahwa anak seakan-akan sudah mulai mempelajari kehidupan sosial dan lingkungan bergaulnya dalam kehidupan sehari-hari.

Pendidikan keagamaan yang ditekankan bagi anaknya sebagaimana direpresentasikan dalam nasehat dan menyampaikan pesan ajaran Islam merupakan langkah yang tepat dalam mendidik akhlak anak. Dalam perkembangan anak, persoalan agama, moral, akhlak, etika, sangat perlu diperhatikan. Hal ini sebagaimana disimpulkan oleh Hadi dalam penelitiannya, menurut Hadi hal tersebut sangat erat, karena semua aspek tersebut sangat kuat kaitannya dengan pembentukan akhlak anak di kemudian hari (Hadi, 2019, p. 318).

Kekhawatiran orang tua terhadap karakter dan perilaku anaknya di masa mendatang merupakan kenyataan yang tidak bisa diabaikan dan ditutup-tutupi. Seorang narasumber menegaskan bahwa memberikan pendidikan agama adalah usaha untuk mengatasi ketakutan yang selama ini dipendam yaitu anaknya nakal, tidak segan, melawan orang tua, dan berandalan, dikarenakan sedikit dan kurang memadainya konsumsi pengetahuan agama. 
Maka mendidik dengan pengetahuan agama, dan aktivitas keagamaan menjadi pilihan yang penting bagi seorang partipasan untuk melatih, mendidik, dan membiasakan dengan nilai-nilai agama, perintah dan larangan ajaran Islam. Kesadaran akan pentingnya pendidikan tersebut, maka orang tua tunggal mengajari baca al-Qur'an dan shalat. Melalui kebiasaan tersebut diharapkan dapat memasukkan secara bertahap nilai-nilai agama. Diperkuat dengan studi yang menyimpulkan bahwa nilai agama dan pendidikan akhlak akan terpadu, dan dapat membentuk pengalaman keagamaan yang diharapkan (Hidayat, 2018, p. 93).

Kesadaran yang dimiliki oleh orang tua tunggal merupakan modal utama untuk menentukan strategi pendidikan akhlak pada anak. Secara umum dapat diketahui, bahwa strategi yang digunakan ialah memberi pemahaman kepada anaknya akan ajaran Islam, keteladanan, kemudian menekankan pada kebiasaan dan menyampaikan pentingnya ajaran Islam dalam kehidupan sehari-hari (Heri Cahyono, 2016, p. 234).

Pendidikan karakter yang ditekankan secara umum ialah pengetahuan agama dan aktivitas keagamaan yang berarti taat melakukan ibadah sesuai ajaran Islam, karena religiusitas dinilai berpengaruh penting dalam mendidik karakter anak (Diana et al. 2021, p. 428). Seperti karakter yang ditekankan ialah bersifat jujur, tolong menolong dan larangan untuk menghina atau mengejek sesama. Hal tersebut merupakan karakter yang sangat dekat dan berhadapan langsung dengan kehidupan anak itu sendiri, baik di dalam keluarga maupun bergaul bersama teman-temannya dan orang lain.

Pendidikan karakter dalam keluarga merupakan hal yang sangat penting, karena hal tersebut menjadi wadah pertama ditemui oleh anak-anak. Sehingga jika pendidikan dalam keluarga sendiri tidak maksimal, atau tidak ada nilai-nilai yang ditanamkan terkhusus akhlak, maka dapat dipastikan bahwa hal tersebut akan berdampak pada karakter ataupun akhlak anak di luar rumah. Lingkungan di luar pengawasan keluarga memberi pengaruh tersendiri, maka peran keluarga demikian signifikan bagi perkembangan anak (Rina Nur Bashiroh et al. 2020, p. $51)$.

Hal di atas merupakan persoalan utama dalam perkembangan anak dan pendidikan akhlak maupun karakter. Di era modern hal tersebut semakin membahayakan kehidupan anak-anak dan menjadi tantangan bagi pendidikan akhlak dan moral dalam keluarga. Oleh karena itu, keluarga tidak dapat menghindari dan mengabaikan pendidikan karakter yang ditanamkan melalui nilai pendidikan dalam Islam atau dilakukan secara berkelanjutan dalam sistem 
keluarga itu sendiri (Muhammad Darwis Dasopang, 2020, p. 117).

Sebagaimana halnya ketika orangtua yang memberikan pendidikan dan pengawasan sekalipun, akan tetapi anak remaja tersebut banyak yang tidak mematuhi perintah dan ajakan orang tuanya. Ditemukan juga bahwa remaja lebih mudah dipengaruhi oleh teman sepergaulannya daripada pengaruh orang tuanya, hal ini mengakibatkan remaja menjauhi ajaran agama (Daulay, 2017, p. 70).

Pendidikan karakter menjadi sebuah upaya dalam menghadapi berbagai tantangan pergeseran perilaku remaja maupun anak yang dihadapi saat ini. Persoalan yang menghambat akan pendidikan karakter dan akhlak anak diantaranya ialah faktor internal, yang mana faktor ini meliputi: naluri, kebiasaan, keturunan, pendidikan dalam keluarga, serta teladan dari kepala keluarga (Hendayani, 2019, p. 183).

\section{Hambatan Single Parent dalam Mendidik Karakter di Desa Talang Belido}

Dalam membimbing dan mendidik anak agar tetap menjunjung tinggi nilai karakter tidak mungkin dapat dilakukan dalam waktu yang singkat. Namun, hal demikian berbeda dengan yang terjadi bagi keluarga orang tua tunggal, yang harus menafkahi keluarga, dan bersamaan itu juga harus mendidik anaknya.

Single parent sebagai orang tua tunggal dan menjadi tulang punggung keluarga memang sulit mengatur waktu sehari semalam untuk memantau pergaulan atau perilaku sehari-hari anaknya dikarenakan sibuk bekerja. Orang tua tunggal harus membesarkan, menyekolahkan anak-anaknya tanpa bantuan suami, karena demikian itulah orang tua tunggal rela atau bahkan harus bekerja banting tulang untuk kehidupan anaknya.

Berdasarkan wawancara dan observasi yang dilakukan penulis di Desa Talang Belido ditemukan beberapa kendala yang dihadapi oleh keluarga single parent dalam mendidik karakter pada anak dalam kehidupan sehari-hari. Adapun beberapa kendala tersebut akan disajikan pada bagian berikut.

\section{Pengaruh Lingkungan}

Salah satu hal yang menghambat pendidikan karakter anak dalam keluarga single parent ialah faktor lingkungan. Kendala ini sangat signifikan mempengaruhi kepribadian anak, oleh karena itu orang tua tidak bisa berupaya menghindari untuk memberi perhatian dan pengawasan terhadap anaknya. Sementara anak lebih banyak menghabiskan waktu bersama teman-temannya yang tidak menutup kemungkinan akan membawa pada aktivitas yang sama, seperti media televisi, handphone, game online dan internet. 
Dengan demikian sesungguhnya kendala yang berat dihadapi oleh single parent ialah mengendalikan lingkungan bermain atau pergaulan anak-anak mereka. Sedangkan anak secara spontan akan mengikuti aktivitas temannya yang baik maupun buruk, maka sesungguhnya lingkungan dapat memberi pengaruh yang mengarah pada kegiatan positif maupun negatif. Tanpa ada pengendalian dan pengawasan serius dari orang tua, misalnya kesibukan orang tua dalam mencari nafkah. Hal demikian menghambat orang tua untuk berinteraksi secara intens dengan anak. Sebagaimana ibu Nani mengakui bahwa kendala yang kerap dihadapi dalam mendidik anak yakni dengan kesibukannya, karena ia harus bekerja sampai sore, jadi sedikit waktu untuk memperhatikan anak-anak setiap harinya. Bahkan waktu untuk bercerita atau berbicara dengan anak-anak sedikit sekali waktunya. Sehingga kadang kesulitan dalam mengawasi perbuatan anak (Nani, 9 Juli 2021, Hambatan Pendidikan Karakter).

Sebagaimana dikemukakan di atas sesungguhnya lingkungan membawa anak pada aktivitas yang dilakukan oleh temannya, misalnya bermain handphone yang sulit diawasi dalam keluarga. Hal demikian secara tegas diungkapkan bahwa kesusahan untuk meningkatkan ilmu agama terhadap anak, dengan terpengaruhnya HP, sehingga lupa dengan semua kewajiban, tidak jarang nasehat orang tua terlebih lagi mereka sering meniru yang ditonton di tv dalam membantah orang tua (Ibu Ade, 11 Juli 2021, Hambatan Pendidikan Karakter).

Pernyataan di atas menampilkan kegelisahan seorang tulang punggung rumah tangga dalam mendidik pengetahuan keagamaan anak. Tanpa keraguan ia mengakui pengaruh handphone membawa efek negatif, seperti sering kali lupa melaksanakan kewajiban agama, demikian juga berkata tidak elegan kepada orang tua, sembari meniru adegan televisi yang tidak bermoral dan tidak menjunjung tinggi karakter.

Senada dengan kenyataan di atas, orang tua Yuli pun mengalami perlakuan yang tidak semestinya dilakukan seorang anak kepada orang tua, hal tersebut sesungguhnya tidak lepas dari pengawasan orang tua yang tidak maksimal. Lebih lanjut berikut pernyataannya:

Anak kami sangat susah kalau dikasih tau, terkadang melawan dan membantah perkataan kami, kadang mereka lebih memilih bermain bersama teman-temannya sampai malam nian hanya untuk bermain game (Ibu Yuli, 12 Juli 2021, Hambatan Pendidikan Karakter).

Pengalaman yang dialami orang tua di atas merupakan kendala yang sangat berat untuk dihadapi seorang single parent. Pengaruh lingkungan yang membawa anaknya untuk bermain game tanpa batas, membuat anak kerap 
melawan dan membantah orang tua mereka. Hal demikian semestinya tidak layak untuk dilakukan oleh seorang anak. Pengaruh game yang membuat anak kecanduan, akhirnya dapat melakukan apa saja, termasuk membantah dan atau melawan arahan dan perintah orang tua.

Ketimpangan atau ketidaklengkapan sistem keluarga atau unsur keluarga di satu sisi menjadi persoalan tersendiri. Namun demikian, kendala lain yang menopang hambatan semakin menguat tidak dapat dihindarkan dalam keluarga single parent. Penelitian ini banyak menemukan kendala atau hambatan yang dialami oleh keluarga orang tua tunggal dalam mendidik akhlak anak, antara lain pengaruh lingkungan.

Pengaruh lingkungan, di masa remaja memang tidak terabaikan dan sulit untuk diawasi secara mendalam dan serius bagi sebuah sistem keluarga yang tidak utuh, seperti single parent. Untuk mengkonfirmasi hal tersebut sebagaimana terlihat jelas penelitian Daulay yang menyatakan bahwa ibu orang tua tunggal banyak yang sibuk mencari nafkah untuk menghidupi keluarganya, sehingga sangat sedikit waktunya untuk memperhatikan pendidikan dan melakukan pengawasan terhadap anak remajanya (Daulay, 2017, p. 69).

Demikian kuat peran pergaulan dan interaksi sosial anak dalam kehidupannya, bagaimanapun proses peniruan dan percobaan yang dilakukan anak kerap diawali dari pertemuannya dengan teman atau bahkan keluarga. Lebih jelas sebagaimana disimpulkan oleh Mujiati dalam penelitiannya bahwa pengaruh teman sebaya terhadap perilaku keberagamaan, demikian juga pengaruh lingkungan keluarga (Andi, 2017, p. 80).

Peranan orang tua untuk menstabilkan lingkungan anak bermain, serta interaksi yang kerap dilakukannya harus menjadi perhatian penting dalam keluarga single parent. Keluarga ini telah kehilangan figur ayah sehingga akan mudah terpengaruh oleh orang lain, karena tidak adanya control dari ayah sebagai pemimpin rumah tangga. Kekuatan orang tua tunggal tentu akan semakin berkurang karena beban keluarga diserahkan atau difokuskan pada satu individu yaitu ibu.

\section{Latar Belakang Pendidikan Orang Tua}

Pendidikan orang tua merupakan hal terpenting dalam mendidik anak, bahkan ia menjadi suatu faktor yang dominan mempengaruhi dalam pendidikan anak karena orang tua adalah lingkungan pertama anak memeroleh pendidikan. Latar belakang pendidikan orang tua banyak mempengaruhi cara berpikir, pola, strategi dalam menghadapi rintangan orang tua dalam mendidik anak- 
anaknnya.

Hal ini dapat dilihat dari hasil wawancara dengan salah seorang narasumber berikut:

Walaupun saya tidak terlalu tahu tentang pendidikan agama, tapi saya selalu menyuruh anak saya untuk mempelajari ilmu agama dan melaksanakan ibadah dan shalat wajibnya, baik pun di rumah, di masjid. Dan malamnya saya pun menyuruhnya mengaji, karena saya tidak mau anak saya seperti saya. Saya memang buta dalam pendidikan agama karena kecil saya tidak pernah mendapat pendidikan agama (Diana, 14 Juli 2021, Hambatan Pendidikan Karakter).

Pernyataan di atas menegaskan bahwa pengetahuan yang dimiliki orang tua akan suatu pendidikan yang diberikan kepada anaknya, menjadi faktor determinan dalam mendidik karakter anak. Orang tua tunggal tersebut menyadari pentingnya pendidikan agama dan pendidikan karakter bagi anaknya. Bagaimanapun seorang single parent yang tidak memiliki latar pendidikan tinggi dan mumpuni, namun ia menaruh harapan besar bagi anaknya untuk menjadi lebih baik dari yang dialami dirinya. Tentu hal tersebut dimotivasi oleh bahwa anaknya tidak boleh mengalami dan merasakan kependihan dan ketidaktahuan orang tuanya dalam hal pengetahuan keagamaan.

Single parent tersebut menyadari ilmu agama, akan memberi dampak positif dan penting bagi karakter anak. Dengan pengetahuan agama yang dimiliki dan kebiasaan beribadah dan taat kepada orang tua dan agama merupakan nilai penting untuk menanam, mendidik dan membentuk anak yang berkarakter, berakhlak, dan menjunjung tinggi moralitas.

Pendidikan yang dilalui oleh orang tua menjadi pertimbangan penting untuk menelaah bagaimana pendidikan karakter diberikan kepada anak. Secara umum pendidikan keagamaan diberikan lebih besar ruangnya untuk menata perilaku dan karakter anak dalam kehidupan sehari-hari. Seorang single parent akan selalu berupaya memberikan pendidikan yang terbaik bagi anaknya, namun dikarenakan pengetahuan yang terbatas, dan latar belakang pendidikan yang tidak memadai sebagian orang tua mempercayai peran lembaga pendidikan Islam untuk mendidik pengetahuan keagamaan dan karakter anakanaknya.

Latar belakang pendidikan sesungguhnya ikut menentukan bagaimana strategi, langkah dan upaya orang tua dalam mendidik nilai karakter yang akan 
diberikan kepada anaknya. Misalnya saja, jika orang tua tersebut telah menempuh studi di perguruan tinggi tentu akan memeroleh bekal yang memadai untuk mendidik anaknya. Secara teoritik, orang tua seperti ini akan mudah mengidentifikasi strategi yang akan diterapkan dalam mendidik anaknya.

Pada konteks ini, sesungguhnya latar belakang pendidikan menentukan akan penanaman dan pendidikan nilai atau internalisasi pendidikan karakter kepada anaknya. Berbekal pengetahuan, sesungguhnya setiap orang mengambil tindakan dan atau keputusan yang memadai. Baik pengetahuan tersebut diperoleh di lembaga pendidikan formal, informal, maupun non formal.

Setiap orang tua, akhirnya mengalami kendala dalam mendidik akhlak anaknya dikarenakan pendidikan yang tidak memadai dan kurangnya pengetahuan untuk mendidik anak, misalnya saja dibutuhkan pemahaman psikologi anak untuk dapat mengerti identitas atau kecenderungan pada seorang anak. Namun, demikian dalam penelitian ini, faktor pendidikan orang tua cukup menghambat dalam pendidikan akhlak kepada anak-anak mereka.

\section{Waktu terbatas atau tidak memadai}

Kendala terakhir yang dialami oleh single parent, yakni faktor dari anak dan orang tua yang terlalu sibuk dengan pekerjaanya. Orang tua dan anak menyibukkan dirinya masing-masing sehingga waktu untuk berinteraksi antar keduanya sangat terbatas. Hal tersebut sebagaimana mengakibatkan kesedihan bagi orang tua karena tidak dapat untuk berbicara atau sekadar berkumpul (Ibu Indah, 17 Juli 2021, Hambatan Pendidikan Karakter).

Demikian juga dialami oleh ibu Mardiana yang sibuk dengan aktivitasnya, namun ia tetap berupaya memberikan yang terbaik untuk pendidikan anaknya, misalnya seperti memberi nasehat. Misalnya ketika di pagi hari dapat berkumpul dan sarapan bersama, tapi tidak dapat bercerita panjang lebar serta bertukar pikiran. Walaupun ia dan anaknya sering sibuk dengan kesibukan masing-masing, ia tetap menasehatinya untuk berperilaku baik (Mardiana, 17 Juli 2021, Hambatan Pendidikan Karakter).

Hambatan yang dialami orang tua tunggal dalam membimbing anakanaknya tidak mengurangi semangat seorang single parent untuk mendidik dengan keterbatasan yang dimilikinya. Oleh karena itu, usaha orang tua tersebut harus diapresiasi dan dipertimbangkan oleh anak yang hendak melakukan perbuatan tercela, atau dilarang oleh norma agama dan sosial.

Orang tua orang tua tunggal di Desa Talang Belido tetap mendorong dan 
memotivasi anak-anaknya untuk melakukan shalat, dan bersifat baik, berlaku sopan kepada orang tua. Seorang single parent selalu menasehati anak-anaknnya karena mereka mengganggap bahwa anak sekarang jika dibiarkan tanpa nasehat, mereka tidak akan mengikuti perintah orang tua, di lain pihak ada juga orang tua yang tidak menasehati seorang anak apabila anak melakukan kesalahan (Observasi, 18 Juli 2021).

Kenyataan yang ditunjukkan di atas mempraktikkan bahwa orang tua yang memperhatikan anak-anak mereka untuk meningkatkan nilai keagaamaan akan tetap terus memberikan dorongan yang tinggi, karena demikian orang tua harus bersikap sabar dalam menghadapi anak-anaknya.

Sebagian masyarakat yang mayoritas lingkungannya yaitu muslim, orang tua tunggal menekankan pada pendidikan keagamaan anak, agar dapat menjadi muslim yang taat. Meskipun demikian perhatian yang diberikan oleh single parent, tidak menutup kemungkinan anak tetap saja belum memiliki nilai karakter, seperti dalam melaksanakan shalat dan mengaji. Seperti usaha yang dilakukan oleh ibu Rahana dengan memasukkan anaknya ke Taman Pendidikan Al-Qur'an (TPA), karena di lembaga tersebut selain belajar mengaji juga diajarkan bacaan-bacaan shalat. Menulis arab dan menghafal doa-doa dan mereka juga melakukan shalat berjama'ah, jadi di taman pendidikan ini anaknya sudah lengkap menerima pendidikan agama yang tidak bisa saya berikan sepenuhnnya di rumah (Rahana , 20 Juli 2021, Hambatan Pendidikan Karakter).

Kesaksian di atas ditambahkan juga oleh orang tua Indah yang menyatakan bahwa dirinya menyadari dengan berbagai kesibukan tersebut dikhawatirkan ia tidak dapat memberikan pendidikan yang baik. Misalnya di TPA mudah menghafal bacaan-bacaan shalat, karena di TPA tersebut bacaan shalat dibaca setiap hari sehingga mempermudah anaknya dalam mengingat dan menghafal (Ibu Indah, 17 Juli 2021, Hambatan Pendidikan Karakter).

Pada konteks ini keterbatasan waktu antara kedua belah pihak memperdalam hambatan pendidikan akhlak diberikan kepada anaknya. Sudah semestinya pendidikan akhlak sebenarnya dapat dilakukan dengan pertemuan antar orang tua dan anak secara terus menerus. Namun, hal tersebut berbeda dengan kasus di atas. Di mana orang tua habis waktu di luar rumah, demikian pula anaknya, bermain dan ketika kembali ke rumah sudah kelelahan yang mengakibatkan tidak tepat untuk berinteraksi atau usaha mendidik, mengajarkan atau memberi nasehat dalam kehidupan sehari-hari.

Dengan demikian menyempatkan atau mengupayakan sisa-sisa waktu untuk mendidik akhlak anak semakin kecil peluangnya. Orang tua akhirnya, 
hanya mengarahkan untuk tekun belajar dan mengikuti pendidikan keagamaan, tanpa ada sentuhan aktif dari orang tua secara langsung. Bagaimanapun keteladanan orang tua patut diperlihatkan untuk memperkuat keyakinan anak dalam bertingkah laku sehari-hari. karena seorang anak tidak hanya butuh teori, pengetahuan untuk membiasakan atau membenarkan perbuatannya. Namun, masih sangat diharapkan contoh tersebut lahir secara langsung dari orang tua yang dianggap sebagai pemimpin dalam keluarganya, karena perkembangan karakter anak akan efektif jika orang tua terlibat dalam pendidikan karakter anak mereka.

TPA dan atau lembaga pendidikan Islam merupakan wadah yang menurut beberapa narasumber dapat memberi pendidikan keagamaan dan mendidik karakter. Dengan kesibukan single parent yang tidak menentu, mereka memberi kepercayaan kepada lembaga pendidikan tersebut untuk mendidik dalam bidang pengetahuan agama dan karakter anak-anaknya.

\section{KESIMPULAN}

Pembahasan di atas memperlihatkan dan menggambarkan kesimpulan berikut: pertama, bahwa pendidikan karakter diberikan oleh ibu single parent hanya semampunya, yang mana orang tua sibuk dengan aktivitas dan tanggung jawabnya untuk menjadi kepala keluarga. Orang tua single parent akhirnya mempercayai kehadiran lembaga pendidikan Islam sebagai wadah pendidikan karakter dan ilmu keagamaan bagi anak-anaknya. Secara khusus single parent memberi arahan dan bimbingan terkait dengan aktivitas religius dan nilai karakter lainnya seperti, kejujuran, dan ketaatan pada agama; kedua, hambatan bagi keluarga single parent dalam mendidik karakter anak di Desa Talang Belido meliputi: pengaruh lingkungan, latar belakang pendidikan orang tua, dan keterbatasan waktu untuk berinteraksi, berbicara, bercerita dan aktivitas lainnya yang berpotensi untuk mendidik, mengarahkan, menasehati anak. Penelitian ini terlihat cukup lugas menjelaskan bagaimana pendidikan karakter tersebut diterapkan dalam sebuah keluarga single parent di Desa Talang Belido. Oleh karena itu, penelitian selanjutnya sangat relevan jika memperlihatkan secara luas bagaimana pendidikan keagamaan yang diperoleh dari di lembaga pendidikan sangat berpotensi dalam mendorong terhadap suatu visi atau penanaman nilai karakter dalam sebuah setting sosial tertentu. 


\section{DAFTAR PUSTAKA}

\section{Buku}

Marzuki. 2015. Pendidikan Karakter Islam. Jakarta: AMZAH.

Muchlis. M. Hanafi, ed. 2010. Pendidikan, Pembangunan Karakter, dan Pengembangan Sumber Daya Manusia (Tafsir Al-Qur'an Tematik). Jakarta: Lajnah Pentashihan Mushaf Al-Qur'an.

Mustoip, Sofyan, Muhammad Japar, dan Zulela Ms. 2018. Implementasi Pendidikan Karakter. Surabaya: CV. Jakad Publishing.

Ni putu Suwardani. 2020. "Quo Vadis" Pendidikan Karakter: dalam Merajut Harapan Bangsa yang Bermartabat. Bali: UNHI Press.

Otib Satibi Hidayat. 2020. Pendidikan Karakter Anak Sesuai Pembelajaran Abad ke-21. Jakarta: Edura-UNJ.

Saepuddin. 2019. Konsep Pendidikan Karakter dan Urgensinya dalam Pembentukan Pribadi Muslim Menurut Imam Al-Ghazali (Telaah atas Kitab Ayyuha al Walad Fi Nashihati al Muta'allimin wa Mau'izhatihim wa Yumayyizuu 'Ilman Nafi'an). Bintan: STAIN Sultan Abdurrahman Press.

Ulfiah. 2016. Psikologi Keluarga: Pemahaman Hakikat Keluarga \& Penanganan Problematika Rumah Tangga. Bogor: Penerbit Ghalia Indonesia.

\section{Artikel/Jurnal}

Aghawenu, N. 2019. "Family Life and Single Parenthood: A Moral Assessment." International Journal of Innovative Psychology \& Social Development 7 (3): 42 46. https://seahipaj.org/journals-ci/sept-2019/IJIPSD/full/IJIPSD-S-62019.pdf

Aynur Pala. 2011. "The Need for Character Education." International Journal Of Social Sciences And Humanity Studies 3 (2): 23-32

Diana, Raden Rachmy, Muhammad Chirzin, Bashori Khoiruddin, Fitriah M. Suud, dan Nadea Zulfa Khairunnisa. 2021. "Parental Engagement On Children Character Education: The Influences Of Positive Parenting And Agreeableness Mediated By Religiosity." Cakrawala Pendidikan 40 (2): 42844.

https://www.researchgate.net/profile/RadenDiana/publication/352958829_PARENTAL_ENGAGEMENT_ON_CHILD REN_CHARACTER_EDUCATION_THE_INFLUENCES_OF_POSITIVE_ PARENTING_AND_AGREEABLENESS_MEDIATED_BY_RELIGIOSITY/ 
links/60e0fb5a299bf1ea9eddede8/PARENTAL-ENGAGEMENT-ONCHILDREN-CHARACTER-EDUCATION-THE-INFLUENCES-OFPOSITIVE-PARENTING-AND-AGREEABLENESS-MEDIATED-BYRELIGIOSITY.pdf

Heri Cahyono. 2016. "Pendidikan Karakter: Strategi Pendidikan Nilai Dalam Membentuk Karakter Religius." Ri'ayah 1 (2): 230-40.

Langea, Marloes de, Jaap Dronkersb, dan Maarten H. J. Wolbers. 2014. "Singleparent family forms and children's educational performance in a comparative perspective: effects of school's share of single-parent families." School Effectiveness and School Improvement 25 (3): 329-50. https://www.tandfonline.com/doi/abs/10.1080/09243453.2013.809773

Maslina Daulay. 2017. “Peranan Ibu Single Parent dalam Perkembangan Sosial dan Perilaku Keagamaan Remaja di Kelurahan Aek Tampang Kota Padangsidimpuan." Tazkir: Jurnal Penelitian Ilmu-ilmu Sosial dan Keislaman 3

http://jurnal.iainpadangsidimpuan.ac.id/index.php/TZ/article/view/720

Muhammad Darwis Dasopang. 2020. "Pola Penanaman Karakter Mulia Terhadap Anak Didik Dalam Keluarga Berdasarkan Nilai Yang Terkandung Dalam Hadits." Tazkir: Jurnal Penelitian Ilmu-ilmu Sosial dan Keislaman $\quad 6 \quad$ (1): $\quad 117-32 . \quad$ http://jurnal.iainpadangsidimpuan.ac.id/index.php/TZ/article/view/2697

Priyono Tri Febrianto. 2021. “Single Mothers' Survival Strategies of University Students During COVID-19 Pandemic." Society 9 (1): 19-36. https://society.fisip.ubb.ac.id/index.php/society/article/view/301

Rina Nur Bashiroh, Erni Munastiwi, Silva Ardiyanti, dan Lely Masruroh. 2020. "Penerapan Pendidikan Karakter Dalam Lingkungan Keluarga Di Era Covid-19." Jurnal Pendidikan Keluarga 12 (2): 50-58.

Rizka Khuswanal Mala. 2017. “Single Parent in Developing Children Character (Case Study on Students at Madrasah Tsanawiyah Ma'arif Kawedusan Pongok Blitar)." Didaktika Religia 5 (2): 423-42. https:/jurnal.iainkediri.ac.id/index.php/didaktika/article/view/869

Sholihah, Abdah Munfaridatus, dan Windy Zakiya Maulida. 2020. "Pendidikan Islam sebagai Fondasi Pendidikan Karakter." Qalamuna: Jurnal Pendidikan, Sosial, dan Agama $12 \quad$ (1): 49-58. https:/ejournal.insuriponorogo.ac.id/index.php/qalamuna/article/view/21 4 
184 | TAZKIR: Jurnal Penelitian Ilmu-ilmu Sosial dan Keislaman

Vol. 07 No. 2 Desember 2021

Succy Primayuni. 2019. "Kondisi Kehidupan Wanita Single Parent." SCHOULID: Indonesian Journal of School Counseling 3 (4): 17-23.

Sukiyani, Fita, dan Zamroni. 2014. "Pendidikan Karakter dalam Lingkungan Keluarga." Socia: Jurnal Ilmu-Ilmu Sosial 11 (1): 57-70. https://journal.uny.ac.id/index.php/sosia/article/view/5290

III. Artikel dalam Prosiding

Setiawati. 2018. "The Role of Character Education in the Family." In Non Formal Education International Conference, 93-95. Atlantis Press. 